\title{
Isotrichid protozoa influence conversion of glucose to glycogen and other microbial products ${ }^{1}$
}

\author{
M. B. Hall ${ }^{2}$ \\ US Dairy Forage Research Center, USDA-ARS, Madison, WI 53706
}

\begin{abstract}
The goal of this in vitro study was to determine the influence of isotrichid protozoa (IP) on the conversion of glucose (Glc) to glycogen (Glyc) and transformation of Glc into fermentation products. Treatments were ruminal inoculum mechanically processed (blended) to destroy IP (B+, verified microscopically) or not mechanically processed $(\mathrm{B}-)$. Accumulated microbial Glyc was measured at $3 \mathrm{~h}$ of fermentation with $(\mathrm{L}+$; protozoa + bacteria) or without $(\mathrm{L}-$; predominantly protozoa) lysis of bacterial cells in the fermentation solids with $0.2 \mathrm{~N} \mathrm{NaOH}$. Two 3 -h in vitro fermentations were performed using Goering-Van Soest medium in batch culture vessels supplemented with $78.75 \mathrm{mg}$ of Glc/vessel in a $26.5-\mathrm{mL}$ liquid volume. Rumen inoculum from 2 cannulated cows was filtered through cheesecloth, combined, and maintained under $\mathrm{CO}_{2}$ for all procedures. At $3 \mathrm{~h}, 0.63$ and $0.38 \mathrm{mg}$ of Glc remained in $\mathrm{B}-$ and $\mathrm{B}+$. Net microbial Glyc accumulation (and Glc in Glyc as \% of added Glc) detected at 3 $\mathrm{h}$ of fermentation were $3.32(4.69 \%),-1.42(-2.01 \%)$, $6.45(9.10 \%)$, and $3.65(5.15 \%) \mathrm{mg}$ for $\mathrm{B}-\mathrm{L}-, \mathrm{B}+\mathrm{L}-$, $\mathrm{B}-\mathrm{L}+$ and $\mathrm{B}+\mathrm{L}+$, respectively. Treatments $\mathrm{B}+$ and $\mathrm{L}+$ gave lower Glyc values than $\mathrm{B}-$ and $\mathrm{L}-$, respectively. Treatment $\mathrm{B}+\mathrm{L}-$ demonstrated net utilization of $\alpha$-glucan contributed by inoculum with no net Glyc production. With destruction of IP, total Glyc accumulation declined by $44 \%$, but estimated bacterial Glyc increased. Microbial accumulation of N increased 17.7\% and calculated $\mathrm{CH}_{4}$ production decreased $24.7 \%$ in $\mathrm{B}+$ compared with $\mathrm{B}-$, but accumulation of $\mathrm{C}$ in microbes, production of organic acids or $\mathrm{C}$ in organic acids, calculated $\mathrm{CO}_{2}$, and carbohydrates in cell-free medium did not differ between $\mathrm{B}+$ and $\mathrm{B}-$. Given the short 3 -h timeframe, increased $\mathrm{N}$ accumulation in $\mathrm{B}+$ was

Received September 30, 2010.

Accepted May 16, 2011.

${ }^{1}$ Mention of any trademark or proprietary product in this paper does not constitute a guarantee or warranty of the product by the USDA or the Agricultural Research Service and does not imply its approval to the exclusion of other products that also may be suitable.

${ }^{2}$ Corresponding author: marybeth.hall@ars.usda.gov
\end{abstract}

attributed to decreased Glyc sequestration by IP rather than decreased predation on bacteria. After correction for estimates of $\mathrm{C}$ from $\mathrm{AA}$ and peptides utilized by microbes, $15 \%$ of substrate Glc $\mathrm{C}$ could not be accounted for in measured products in $\mathrm{B}+$ or $\mathrm{B}-$. Approximately $30 \%$ of substrate Glc was consumed by energetic costs associated with Glc transport and Glyc synthesis. The substantial accumulation of Glyc and changes in microbial $\mathrm{N}$ and Glyc accumulation related to presence of IP suggest that these factors should be considered in predicting profiles and amounts of microbial products and yield of nutrients to the cow as related to utilization of glucose. Determination of applicability of these findings to other soluble carbohydrates could be useful. Key words: sugar, protozoa, rumen fermentation, nonfiber carbohydrate

\section{INTRODUCTION}

Fermented carbohydrate is the primary energy source that supports microbial protein production in the rumen. By affecting microbial protein production, fermentable carbohydrate has the potential to affect production measures that can be influenced by protein supply. Compared with providing starch sources, provision of sugars in the diets of dairy cattle has yielded mixed results in effects on milk protein production and efficiency of dietary $\mathrm{N}$ utilization. No differences in milk protein production were detected among carbohydrate treatments when cows were supplemented with sugar or starchy feeds on diets containing fresh annual ryegrass (dietary $\mathrm{CP}=19.9 \%, \mathrm{NFC}=36 \% \mathrm{DM}$ basis; McCormick et al., 2001) or when cows were supplemented with purified sugar or starch on diets based on alfalfa and corn silages (dietary CP $16.8 \%$, NFC 43\%, DM basis; Broderick et al., 2008). In contrast, with cows fed relatively low protein (CP $15.6 \%$ of $\mathrm{DM})$ and high NFC (47\% of DM) diets, a quadratic response in milk protein production was reported for substitution of liquid molasses for high-moisture corn (Broderick and Radloff, 2004). In that study, milk protein production increased with the initial $3 \%$ of diet DM increase in molasses, followed by a return to the performance level of the control diet with greater molasses supplementation. 
In terms of efficiency of feed $\mathrm{N}$ utilization ( $\mathrm{N}$ in milk/ $\mathrm{N}$ in consumed DMI), studies have shown linear decreases in efficiency when dietary sugar concentrations are increased largely at the expense of starchy feeds on diets with high or moderate concentrations of CP (18.0\% and $16.8 \%$ of DM; dietary NFC: $42 \%$ and $43 \%$ of DM; values from Broderick and Radloff, 2004 and Broderick et al., 2008, respectively). This response was associated with increased DMI and limited to no change in milk protein production as dietary sugar concentrations increased. In a study in which cows were provided with relatively low protein, high NFC diets containing $0,3,6$, or $9 \%$ liquid molasses substituted for high-moisture corn, a linear decline $(P=0.02)$ or more variable cubic response $(P=0.01)$ in $\mathrm{N}$ use efficiency were noted (diet composition: $15.6 \%$ CP, $47 \%$ NFC, $\%$ of DM; Broderick and Radloff, 2004). Allowing that cow performance responses to dietary carbohydrates are based on changes in supplies of microbial and enzymatic digestion products, we need to assess factors that modify profiles or amounts of these products to understand the basis for variable animal responses.

Both ruminal protozoa and bacteria can ferment sugars directly to produce organic acids, gases, and microbial cells, or can convert them to glycogen (Thomas, 1960). Glycogen is an $\alpha$-glucan intracellular storage polysaccharide with $\alpha-(1,4)$ and $\alpha-(1,6)$ linkages as in starch; it can be produced from glucose, fructose, sucrose, and fructan (Masson and Oxford, 1951). Isotrichid protozoa in particular have been reported to accumulate glycogen when provided with sugar or fructan substrates (Masson and Oxford, 1951). Additionally, ruminal protozoa exhibit chemotaxy toward sugars (Murphy et al., 1985), suggesting that sugars are preferred substrates for these microbes. Glycogen represents dietary carbohydrate that has been sequestered, but not yet fermented and so has not yet provided energy for microbial maintenance or growth. Accordingly, increases in the proportion of carbohydrate substrate converted to glycogen may decrease the rate of microbial cell and protein production relative to the rate possible from fermentation of the original substrate. The effect of glycogen sequestration by protozoa on overall microbial cell yields is not known. Assessment of glycogen accumulated by protozoa or bacteria and the effect on yield of fermentation products may help to clarify the impact of carbohydrate storage as contributed by each pool of microorganisms.

The objective of this study was to evaluate the effect of the relative presence or absence of isotrichid protozoa (IP) on the accumulation of glycogen in protozoal and bacterial cells and on the production of other microbial products. The fermentation study was performed in vitro using glucose as a model sugar, because animal sys- tems are too complex to allow testing of the principles investigated here. A short fermentation time was used to obtain maximal glycogen accumulation and reduce artifacts that may be produced in longer fermentations.

\section{MATERIALS AND METHODS}

The treatments in this study were use of ruminal inoculum that was or was not mechanically processed to destroy large IP, and measurement of glycogen accumulated by protozoa or by protozoa + bacteria by omission or use of a treatment for lysis of bacteria before $\alpha$-glucan analysis (Figure 1).

\section{Fermentation}

Duplicate 3-h fermentation runs were performed using Goering-Van Soest medium (Goering and Van Soest, 1970 ) in sealed glass fermentation tubes (121 mm long, $28 \mathrm{~mm}$ outer diameter, $2.8 \mathrm{~mm}$ wall thickness, sealed with crown caps). The 3 -h duration was selected as giving the point of maximum accumulation of glycogen by the IP (Masson and Oxford, 1951). Each vessel contained $20 \mathrm{~mL}$ of medium and $1 \mathrm{~mL}$ of reducing solution (Goering and Van Soest, 1970), $5 \mathrm{~mL}$ of ruminal inoculum, and $0.5 \mathrm{~mL}$ of autoclaved distilled water or autoclaved glucose solution that delivered $78.75 \mathrm{mg}$ of glucose (G-7021, Sigma Aldrich Co., St. Louis, MO). The medium supplied $40.9 \mathrm{mg}$ of $\mathrm{CP}$ from tryptone (pancreatic digest of casein, T-9410, Sigma-Aldrich Co.), $22.1 \mathrm{mg}$ of CP from ammonium bicarbonate, and $3.1 \mathrm{mg}$ of $\mathrm{CP}$ from cysteine-HCl.

Inoculum Preparation. Inoculum for each fermentation was obtained from 2 lactating Holstein cows maintained under protocols approved by the University of Wisconsin College of Agriculture and Life Sciences Animal Care and Use Committee. The donor cows were fed a TMR consisting of, on a DM basis, 30\% corn grain, $30 \%$ corn silage, $30 \%$ alfalfa haylage, and $10 \%$ soybean meal, with supplemental vitamins and minerals to meet NRC (2001) recommendations. Ruminal contents obtained from each cow within $2 \mathrm{~h}$ postfeeding were strained through 4 layers of cheesecloth, and the rumen liquor was maintained under $\mathrm{CO}_{2}$. Rumen liquor from each cow $(500 \mathrm{~mL}$ each) was measured and filtered through an additional 4 layers of cheesecloth, with rumen fluid from both cows combined in a common flask maintained at $39^{\circ} \mathrm{C}$ in a water bath with $\mathrm{CO}_{2}$ bubbled continuously through the liquor. The $\mathrm{pH}$ of rumen contents obtained from individual cows ranged from 5.93 to 6.16 .

A specially designed stainless steel blender insert (Figure 2) was used to mechanically destroy IP in the inoculum. Two fins of the insert extended in from the 


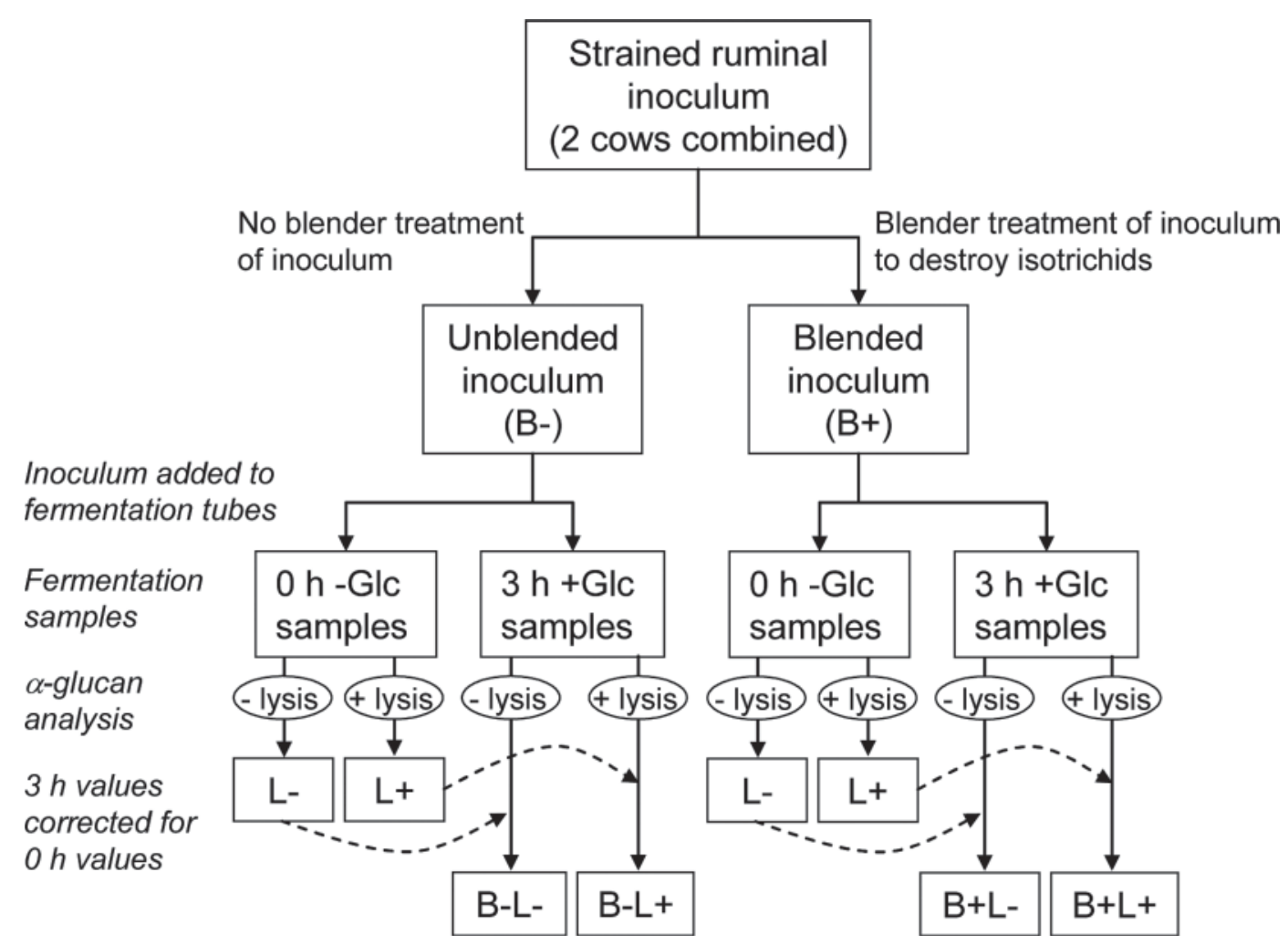

Figure 1. Experimental protocol. Inoculum treatments gave inoculum that had the full complement of bacteria and protozoa (B-) or lacked the large isotrichid protozoa $(\mathrm{B}+)$. Lysis treatments used with the $\alpha$-glucan assays allowed for analysis of glycogen and starch in protozoa and feed $(\mathrm{L}-)$ or in protozoa, feed, and bacteria $(\mathrm{L}+) .-\mathrm{Glc}=$ no glucose added, $+\mathrm{Glc}=$ glucose substrate added. For the glycogen evaluation treatments $\mathrm{B}-\mathrm{L}-=$ unblended inoculum, no NaOH lysis; $\mathrm{B}-\mathrm{L}+=$ unblended inoculum, with $\mathrm{NaOH}$ lysis; $\mathrm{B}+\mathrm{L}-=\mathrm{blended}$ inoculum, no NaOH lysis; $\mathrm{B}+\mathrm{L}+=$ blended inoculum, with $\mathrm{NaOH}$ lysis.

corners on opposite sides of the stainless steel blending carafe for the entire interior height of the blender (model HGB-300 Waring Commercial Blender, Waring, New Hartford, CT) but did not impede the blades. A mechanical system was used to avoid the possibility that chemicals used for defaunation would have side activity that would affect the fermentation results. The common flask of rumen liquor was swirled by hand to mix, and $400 \mathrm{~mL}$ each was transferred to the blender carafe and to a 500-mL Erlenmeyer flask on the bench. Both vessels were maintained at ambient temperature during inoculum blending, and headspaces flushed continuously with $\mathrm{CO}_{2}$. Inoculum in the blender was subject to eight 12 -s blendings on the "high" setting and the blade was allowed to stop before the next blending was started. Clean cheesecloth was used to remove foam from the interior top of the blender after the first 2 blendings to lessen the possibility that undamaged IP would survive there to contaminate the inoculum. The blended inoculum was transferred to an Erlenmeyer flask continuously flushed with $\mathrm{CO}_{2}$. The flasks of the blended $(\mathbf{B}+)$ and unblended $(\mathbf{B}-)$ inocula were transferred to a $39^{\circ} \mathrm{C}$ water bath and the headspace flushed with $\mathrm{CO}_{2}$ as the $\mathrm{pH}$ was taken. The $\mathrm{pH}$ values of the inocula were as follows: $\mathrm{B}-=6.08$ and 6.05 , and $\mathrm{B}+=$ 6.05 and 6.06 for the first and second fermentations, respectively. Both inocula were maintained at $39^{\circ} \mathrm{C}$ with $\mathrm{CO}_{2}$ bubbled continuously through them until inoculation of fermentation vessels.

Fermentation Samples. For the $0 \mathrm{~h}$ of fermentation, 10 fermentation tubes per inoculum type were prepared with $0.5 \mathrm{~mL}$ of water added and no glucose solution. Three tubes were used for analysis of organic acids, 3 for carbon (C) and nitrogen (N) analysis of the cell pellet, and 4 for analysis of $\alpha$-glucan. For 3 $\mathrm{h}$ of fermentation, 13 tubes per inoculum type were prepared: 3 with $0.5 \mathrm{~mL}$ of water added to serve as fermentation blanks for organic acid analysis, and 10 with $0.5 \mathrm{~mL}$ of glucose solution added for organic acid and $\mathrm{pH}$ analysis (3 tubes), $\mathrm{C}$ and $\mathrm{N}$ analysis of the cell pellet (3 tubes), and analysis of $\alpha$-glucan (4 tubes). In the second fermentation, an additional 2 tubes per inoculum per hour with glucose as a substrate at 3 $\mathrm{h}$ were added for evaluation of the bacterial population profile by inoculum and hour. After inoculation, purging of headspace with $\mathrm{CO}_{2}$, and sealing with crown 


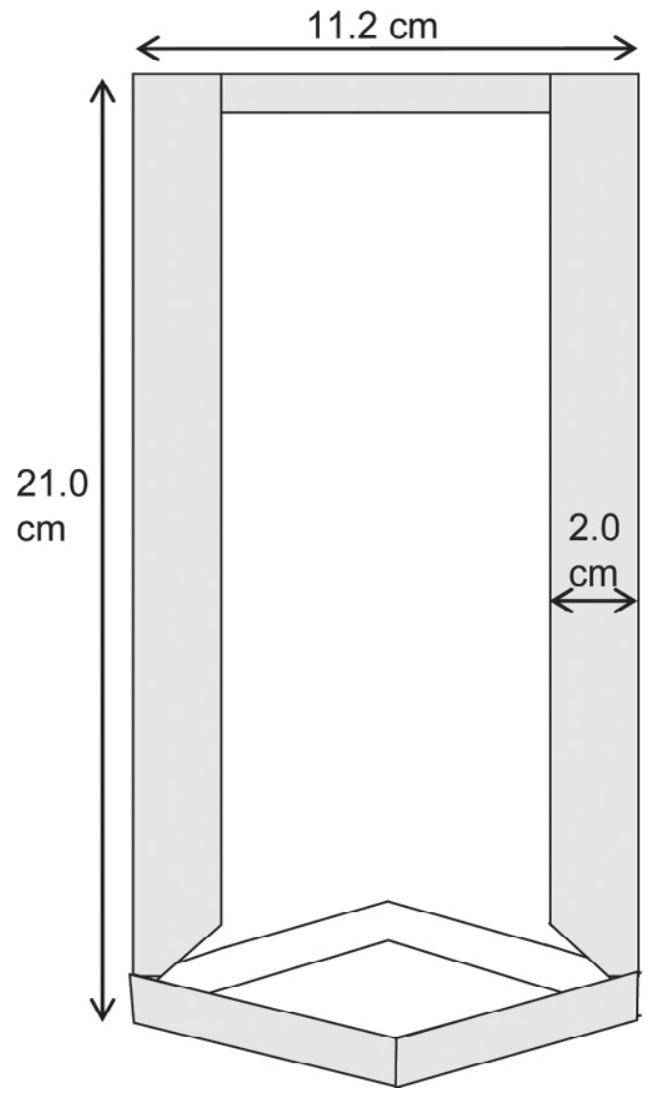

Figure 2. Stainless steel blender insert used for mechanical destruction of large isotrichid protozoa.

caps, tubes were incubated at $39^{\circ} \mathrm{C}$ for $3 \mathrm{~h}$ at $160 \mathrm{rpm}$ in an incubating orbital shaker (Innova 40, New Brunswick Scientific, Edison, NJ), with tubes set horizontally in racks, parallel to the motion of the shaker.

At each sampling hour, harvested tubes were placed immediately in ice to stop the fermentation. Two tubes were uncapped and $\mathrm{pH}$ measured immediately. Fermentation contents of these tubes were transferred to two $20-\mathrm{mL}$ scintillation vials and stored at $-20^{\circ} \mathrm{C}$ until analyzed for organic acids, free monosaccharides, or polymerized soluble carbohydrate. Samples destined for $\mathrm{C}, \mathrm{N}$, or $\alpha$-glucan analysis were transferred quantitatively with $0.9 \% \mathrm{NaCl}$ rinses to $50-\mathrm{mL}$ centrifuge bottles (\#357001, Beckman Coulter Inc., Brea, CA) and centrifuged at $13,000 \times g$ for $45 \mathrm{~min}$ at $5^{\circ} \mathrm{C}$. The supernatant was decanted and discarded. Pellets were disturbed with a spatula, resuspended in $0.9 \% \mathrm{NaCl}$, and centrifuged again at $13,000 \times g$ for $45 \mathrm{~min}$ at $5^{\circ} \mathrm{C}$. The supernatant was discarded. Fermentation pellets for $\mathrm{C}$ and $\mathrm{N}$ analysis were transferred using $0.9 \% \mathrm{NaCl}$ rinses to disposable $50-\mathrm{mL}$, screw-cap conical tubes for lyophilization. Samples for $\alpha$-glucan analysis were stored in the centrifugation bottles at $4^{\circ} \mathrm{C}$ and analyzed on the day of the fermentation.

\section{Analyses}

Fermentation pellets were analyzed for $\mathrm{C}$ and $\mathrm{N}$ (Dumas combustion method, Leco FP-2000, Leco Corp., St. Joseph, MI). Carbon and $\mathrm{N}$ accreted by microbes were calculated as the 3 -h values minus $0-h$ average values within inoculum treatment to correct for insoluble material introduced with the inoculum. Organic acid concentrations in samples of medium were analyzed by HPLC (Weimer et al., 1991). Values for organic acids were corrected for the average of the fermentation blanks by inoculum treatment for the sampling hour, except for branched-chain VFA, which were corrected for 0 -h values. Total organic acid values reported are the sum of acetate, propionate, butyrate, valerate, and lactate and should come predominantly from carbohydrate. Valerate can be produced directly from carbohydrate (Marounek et al., 1989), but may also be produced from condensation of 2- and 3-carbon compounds (Wolin, 1960), which could come from carbohydrate fermentation or may be produced from the fermentation of proline (El-Shazly, 1952). Because valerate can be produced from proline, its inclusion may result in a slight overestimation of the total organic acids that are attributable to fermentation of the glucose substrate. Consistent with the attribution of valerate as a carbohydrate fermentation product, the amount of hexose fermented as calculated from the organic acids produced was 1 hexose/2 acetate +1 hexose/2 propionate +1 hexose/1 butyrate (from the stoichiometric equations of Hungate, 1966) +1 hexose/2 lactate +1 hexose/1 valerate.

Production of $\mathrm{CH}_{4}$ and $\mathrm{CO}_{2}$ was estimated from organic acid production according to the stoichiometric equations of Hungate (1966). These equations presume that no organic acid was produced from substrates other than carbohydrate. Because of the uncertainty regarding the substrate source of valerate, and thereby lacking information on the gas associated with its production, valerate was not included in estimations of gas production.

Carbohydrates in Fermentation Medium. Free monosaccharides and polymerized soluble carbohydrates in the medium were measured in the supernatant of samples centrifuged at $12,000 \times g$ for $1 \mathrm{~h}$ at $5^{\circ} \mathrm{C}$. All samples were filtered through preparatory columns to remove protein (Waters Sep-Pak vac 1-mL C18 cartridges, Waters Corp., Milford, MA) before hydrolysis or direct analysis of the medium. Polymerized soluble carbohydrate was hydrolyzed using $2 N$ trifluoroacetic acid $\left(90 \mathrm{~min}, 120^{\circ} \mathrm{C}\right)$ followed by analysis of the released sugars. All monosaccharides were measured as alditol acetates (Harris et al., 1988) by GC [FID-GLC on a Shimadzu GC2010, Shimadzu Scientific Instruments, 
Columbia, MD; Quadrex (50\% cyanopropylphenyl) Methylpolysiloxane column $30 \mathrm{~m} \times 0.25 \mathrm{~mm}$ with 0.25 $\mu \mathrm{m}$ film thickness]. The gas-liquid chromatography conditions were injector $220^{\circ} \mathrm{C}$, detector $240^{\circ} \mathrm{C}$, and a temperature program of $215^{\circ} \mathrm{C}$ for $2 \mathrm{~min}$, increasing at $4^{\circ} \mathrm{C} / \mathrm{min}$ to $230^{\circ} \mathrm{C}$, and holding for $11.25 \mathrm{~min}$. Peaks were authenticated using model compounds. Polymerized soluble carbohydrate was expressed on a monosaccharide basis and corrected for free monosaccharides present. Originally, we attempted to measure residual free glucose in the medium with a glucose oxidaseperoxidase assay (Hall and Keuler, 2009); however, the medium interfered with glucose detection by that assay (likely an effect of the chemicals used to reduce the medium). Glucose utilized in the fermentation was calculated as glucose added minus residual glucose at 3 $\mathrm{h}$ of fermentation.

$\boldsymbol{\alpha}$-Glucan. Estimation of glycogen stored by protozoa + bacteria or protozoa alone was accomplished with use or omission of a step for bacterial lysis in $\alpha$-glucan analysis schemes. Without a cell wall, protozoa are more fragile than bacteria and the glycogen they contain can be analyzed without inclusion of a lysis step $(\mathbf{L}-)$. In contrast, analysis of glycogen in bacterial cell contents requires lysis of the cells $(\mathbf{L}+)$ to make the contents available. Lysis can be accomplished with alkali treatment (Wells and Russell, 1996). Corrected for glycogen in 0 - $\mathrm{h}$ samples, the $\mathrm{L}-$ values describe glycogen in protozoal cells, L+ values describe glycogen in protozoa + bacteria, and the difference between $\mathrm{L}+$ and $\mathrm{L}-$ estimates the glycogen in bacteria. By this method, glycogen in $\mathrm{B}-\mathrm{L}+$ represents glycogen stored in bacteria and the full complement of ruminal protozoa sampled (includes large isotrichids); B-L- represents glycogen in the full complement of protozoa (includes isotrichids) without bacteria; in $\mathrm{B}+\mathrm{L}-$ glycogen is from protozoa (excluding large isotrichids) without bacteria; and in $\mathrm{B}+\mathrm{L}+$ the measured glycogen is that from bacteria and protozoa (excluding large isotrichids).

Fermentation pellets from $\mathrm{B}-$ and $\mathrm{B}+$ treatments, isolated corn starch (as a control sample), and a reagent blank were analyzed for $\alpha$-glucan with or without $\mathrm{NaOH}$ lysis of bacterial cells. When referring to contributions of $\alpha$-glucan brought in with the original inoculum at $0 \mathrm{~h}$, the term " $\alpha$-glucan" is used because it is unknown if the source was feed or microbes. The term "glycogen" will be used when referring to net $\alpha$-glucan accumulated by protozoa or bacteria during the fermentations.

For treatment $\mathrm{L}-$ (nonlysis analysis for $\alpha$-glucan), fermentation pellets were quantitatively transferred with $0.1 \mathrm{M} \mathrm{Na}$ acetate buffer to $25-\times 150-\mathrm{mm}$ tubes with polytetrafluoroethylene-lined screw caps and analyzed according to the sodium acetate buffer method described by Hall (2009). Final sample volume was approximately $51.1 \mathrm{~mL}$, with the actual volume determined by solution weight and density.

Fermentation pellets to be lysed with $\mathrm{NaOH}$ (treatment $\mathrm{L}+$ ) were quantitatively transferred to $50-\mathrm{mL}$ beakers with $0.2 \mathrm{M} \mathrm{NaOH}$ and brought to a volume of approximately $20 \mathrm{~mL}$. Samples were stirred on a magnetic stir plate to mix, capped with aluminum foil, and incubated in a boiling water bath for $15 \mathrm{~min}$. After cooling on the bench, samples were adjusted to $\mathrm{pH} 5.0$ \pm 0.05 with $15 \%$ acetic acid. Heat-stable $\alpha$-amylase (0.1 mL, 1740 liquefon units; Multifect AA, Genencor International, Rochester, NY; origin: Bacillus licheniformis) and amyloglucosidase (200 units in $1 \mathrm{~mL}$ with Na acetate buffer; E-AMGDF, Megazyme International Ireland Ltd., Bray, Co. Wicklow, Ireland; origin: Aspergillus niger) were added to each sample. Samples were capped with aluminum foil, stirred on a magnetic stir plate, and then incubated for $2 \mathrm{~h}$ in a $50^{\circ} \mathrm{C}$ water bath with samples stirred at $1 \mathrm{~h}$. Samples were filtered through glass wool into $50-\mathrm{mL}$ volumetric flasks and brought to volume with distilled water. Sample solutions were centrifuged at $1,000 \times g$ to clarify them and subjected to the same glucose oxidase-peroxidase analysis for released glucose as for L- samples (Hall and Keuler, 2009).

$\alpha$-Glucan was calculated as released glucose $\times 0.9$. Net accumulated glycogen was calculated as 3 -h values corrected for the average value of the 0 -h fermentation blank for the specific inoculum type used. The 0 -h fermentation blank allowed correction for $\alpha$-glucan introduced by the rumen inoculum, but did not account for fermentation of introduced dietary $\alpha$-glucan during the incubations. Glycogen values can be expressed as the equivalent amount of substrate glucose by the calculation: glycogen $\mathrm{mg} / 0.9$.

Evaluation of Microbes. Inoculum was evaluated microscopically for the presence of large IP as an indicator of efficacy of the blending treatment. Nine approximately evenly spaced fields (3 across the top, middle, and bottom sections of a slide) in each of 5 microscope slides for each undiluted inoculum were evaluated for the presence of the large isotrichid protozoa using the $5 \times$ objective and 1.6 optovar of a Zeiss Axioskop microscope (Karl Zeiss Microimaging Inc., Thornwood, NY). Each flask of inoculum was swirled to mix and separate subsamples taken for each slide.

Qualitative evaluation of the number of intact bacteria remaining after $\alpha$-glucan analysis was performed on $\mathrm{L}-$ and $\mathrm{L}+$ samples from fermentation 2 to determine if a difference existed between treatments in efficacy of cell lysis. A bacterial viability assay (LIVE/DEAD BacLight fluorescence-based assay, Invitrogen Corp., Carlsbad, CA) was used. Four separate samples each 
of $\mathrm{L}-$ and $\mathrm{L}+$ treatments of cultures fermented for 3 $\mathrm{h}$ with glucose were evaluated. Dead intact microbial cells stained red and live microbial cells stained green in this assay.

An automated ribosomal intergenic spacer analysis (ARISA) evaluation was performed in the second fermentation on 2 fermentation tubes from each inoculum treatment at 0 and $3 \mathrm{~h}$ to evaluate whether blending altered the gross bacterial population profile. The 0 - $h$ tubes contained no added substrate, and the 3-h tubes contained glucose as a substrate. The ARISA assay was performed as described by Weimer et al. (2010).

\section{Calculations}

Carbon values for microbial products and substrates were calculated as milligrams of $\mathrm{C}$ accumulated by $3 \mathrm{~h}$ in the fermentation pellet, $0.40 \mathrm{mg}$ of $\mathrm{C} / \mathrm{mg}$ of glucose, mannose, or galactose; $0.439 \mathrm{mg}$ of $\mathrm{C} / \mathrm{mg}$ of rhamnose; $12 \mathrm{mg}$ of $\mathrm{C} / \mathrm{mmol}$ of $\mathrm{CO}_{2} ; 12 \mathrm{mg}$ of $\mathrm{C} / \mathrm{mmol}$ of $\mathrm{CH}_{4} ; 24$ $\mathrm{mg}$ of $\mathrm{C} / \mathrm{mmol}$ of acetate; $36 \mathrm{mg}$ of $\mathrm{C} / \mathrm{mmol}$ of propionate; $48 \mathrm{mg}$ of $\mathrm{C} / \mathrm{mmol}$ of butyrate; $60 \mathrm{mg}$ of $\mathrm{C} / \mathrm{mmol}$ of valerate; and $36 \mathrm{mg}$ of $\mathrm{C} / \mathrm{mmol}$ of lactate. Total $\mathrm{C}$ in products was the sum of cell pellet, $\mathrm{CO}_{2}, \mathrm{CH}_{4}$, organic acids, and soluble carbohydrate in the fermentation medium that responded to glucose supplementation, exclusive of free glucose in the medium.

Microbial growth efficiency expressed as grams of microbial cell $\mathrm{N}$ per kilogram of hexose fermented was calculated for each treatment in each fermentation as 1,000 multiplied by the arithmetic averages of the weights (mg) of cell pellet $\mathrm{N}$ accumulated during the fermentation divided by milligrams of hexose actually fermented. As described previously, hexose fermented was calculated from the organic acids produced.

Estimates of glycogen ( $\mathrm{g} / \mathrm{kg}$ of microbial cell mass) were calculated as $[(1 \mathrm{~g} / 1,000 \mathrm{mg}) \times$ glycogen $\mathrm{mg}] /$ [(glycogen $\mathrm{mg}+$ estimated non-glycogen cell mass $\mathrm{mg}$ ) $\times(1 \mathrm{~kg} / 1,000,000 \mathrm{mg})]$. Non-glycogen cell mass was estimated as milligrams of cell pellet $\mathrm{N} / 0.112$. The 0.112 factor comes from the report of Pavlostathis et al. (1988), who described an average, non-glycogencontaining microbial cell composition as $90 \%$ OM with a chemical composition of $\mathrm{C}_{5} \mathrm{H}_{7} \mathrm{O}_{2} \mathrm{~N}$. The 0.112 factor is derived from $0.9 \mathrm{OM}$ proportion $\times(14 \mathrm{~g} / \mathrm{mol}$ of $\mathrm{N}) /$ $\left(113 \mathrm{~g} / \mathrm{mol}\right.$ of $\left.\mathrm{C}_{5} \mathrm{H}_{7} \mathrm{O}_{2} \mathrm{~N}\right)$. Least squares means values were used for these calculations.

\section{Statistical Analysis}

Variables used for evaluation of glycogen production were $R_{i}=$ fermentation run $(i=1,2), B_{j}=$ inoculum blending $\left(\mathrm{j}=\right.$ yes or no), $\mathrm{L}_{\mathrm{k}}=$ microbial lysis treatment $(\mathrm{k}=$ yes or no), and their interaction terms. For all other measures, the same variables were used except for the microbial lysis treatment, which was only relevant to glycogen. Terms for hour of fermentation $\left(\mathrm{H}_{1}, \mathrm{l}=\right.$ 0 or 3 ) and its interactions with other variables were included for comparisons between fermentation hours. Excepting ARISA data evaluation, all analyses were performed using the MIXED procedure of SAS (version 8.0, SAS Institute Inc., Cary, NC), with fermentation run treated as a random variable. Values are reported as least squares means. Significance was declared at $P$ $<0.05$, and tendencies at $0.05 \leq P<0.15$. Data from the ARISA assay were analyzed using an analysis of similarity (Clarke, 1993).

\section{RESULTS AND DISCUSSION}

\section{Efficacy of Treatments}

Microscopic evaluation of inocula for the presence of large IP indicated that the blending treatments were apparently successful in eliminating these glycogenaccumulating protozoa. In the first fermentation, 12 large IP were found in 8 of 45 fields for $\mathrm{B}$ - and none were found in $\mathrm{B}+$; in the second fermentation, $20 \mathrm{IP}$ were found in 17 of 45 fields for $\mathrm{B}-$ and none for $\mathrm{B}+$. Numerous smaller, live protozoa, which appeared to be primarily entodiniomorphids, were present in both inocula in both fermentations. Additional visual scans of the $\mathrm{B}+$ inoculum slides beyond the formal evaluation did not detect the presence of the large IP. Consequently, B- inoculum contained the full complement of ruminal protozoa sampled, and $\mathrm{B}+$ also contained protozoa but lacked the large isotrichids. Complementary to these observations, white sediment was observed after $3 \mathrm{~h}$ of fermentation in the glucose-containing tubes for $\mathrm{B}$ - but not for $\mathrm{B}+$. Microscopic examination of the sediment from previous fermentations of sucrose or glucose showed it to be composed of IP laden with glycogen granules. The sedimentation of protozoa cultured on soluble carbohydrate substrates has been reported (Masson and Oxford, 1951). The large IP in the inoculum at the start of the fermentations appeared to contain varying amounts of starch granules; glycogen granules were not identifiable at the magnification used. That these protozoa were partially filled with stored or ingested carbohydrate at the start of the fermentation may have reduced the total amount of glycogen they sequestered during fermentation, perhaps making the study results more comparable to responses to subsequent rather than initial meals consumed by a cow.

The ARISA evaluation of the 0 - and 3 -h bacterial population profiles in the second fermentation showed that $\mathrm{B}-$ and $\mathrm{B}+$ did not differ $(P=0.97)$, indicating that the blending treatment did not alter the bacte- 
rial population of the inocula. However, both inocula profiles were affected by time, with 0 - and 3 -h profiles differing for $\mathrm{B}-$ and $\mathrm{B}+(P<0.01$ for both $)$. The difference by time likely reflects the shift in populations related to changing from TMR to glucose as the substrate and growth under in vitro conditions.

Evaluation of samples for intact microbes after $\alpha$-glucan analysis showed that bacteria were largely lysed with the $\mathrm{NaOH}$ treatment, with few unlysed, dead bacterial cells remaining. Qualitatively, considerably more intact dead microbes were observed with $\mathrm{L}-$ than with $\mathrm{L}+$, including a few intact protozoa (not apparently isotrichid in form), and no intact protozoa were noted for L+. Surprisingly, very rare, apparently live (green-staining) bacteria were noted in both $\mathrm{L}-$ and L+, suggesting that some microbes may survive hours of postfermentation manipulation.

Inoculum donor cows consumed diets composed of feeds low in free glucose, which raised the question of whether the microbes harvested would be adequately adapted to glucose utilization. The yields of microbial cell $\mathrm{N}$ (in $\mathrm{g} / \mathrm{kg}$ of estimated hexose fermented) were 55 and 52 for $\mathrm{B}+$ and 50 and 42 for $\mathrm{B}$ - in fermentations 1 and 2 , respectively. These values of bacterial growth efficiency are numerically greater than values determined with glucose as a substrate with mixed ruminal bacteria in a chemostat $(39.8 \pm 2.2 \mathrm{~g}$ of $\mathrm{N}$ incorporated $/ \mathrm{kg}$ of OM fermented, dilution rate of $0.144 \mathrm{~h}^{-1}$; Van Nevel and Demeyer, 1979). It is granted that the degree of microbial recycling in a short, 3-h fermentation may be less than in a chemostat and, thus, give greater microbial N production per hexose. Nonetheless, the growth efficiencies noted and the almost complete disappearance of glucose substrate suggest that the microbes in the present study were able to utilize glucose efficiently despite the fact that the cows were not specially adapted to this substrate. It is recommended that inoculum donors be adapted to the substrates that the microbes will encounter in vitro.

\section{Fermentation Products}

The glucose substrate was almost entirely fermented in both blending treatments, with 0.63 and $0.38 \mathrm{mg}$ of the original $78.75 \mathrm{mg}$ remaining after $3 \mathrm{~h}$ of fermentation for $\mathrm{B}-$ and $\mathrm{B}+$, respectively (standard error of the difference $=0.102 ; P=0.07$ ). Final $\mathrm{pH}$ of the 3 -h fermentation vials containing glucose were 6.59 and 6.63 for $\mathrm{B}-$ and $\mathrm{B}+$, respectively, and did not differ $(P$ $=0.56$, standard error of the difference $=0.07$ ).

Glycogen. Glycogen accumulation at $3 \mathrm{~h}$ of fermentation differed by inoculum treatment, lysis treatment, and their interaction (Table 1). Alkaline lysis $(\mathrm{L}+)$ increased the amount of glycogen detected for B- and $\mathrm{B}+$, which supports the need for lysis in measurement of bacterial cell contents. The $99.8 \%$ recovery for corn starch control samples in the $\alpha$-glucan assays for both $\mathrm{L}-$ and $\mathrm{L}+$ indicated that the assays had equivalent efficacy for measuring insoluble $\alpha$-glucan.

Both protozoa and bacteria accumulated substantial amounts of glycogen. Net glycogen accumulation by protozoa in $\mathrm{B}-\mathrm{L}$ - accounted for $4.7 \%$ of glucose substrate, whereas the negative value for $\mathrm{B}+\mathrm{L}-$ represents fermentation of $\alpha$-glucan introduced with the inoculum and no or limited accumulation of glycogen by the remaining protozoa (apparently primarily entodiniomorphids). These results agree with the comment of Masson and Oxford (1951) that whereas $3 \mathrm{~h}$ of fermentation was adequate for maximal polysaccharide storage by holotrichs (isotrichids), an overnight fermentation was better for maximizing polysaccharides storage in oligotrichs (entodiniomorphids). The negative value for $\mathrm{B}+\mathrm{L}-$ also suggests that net glycogen accumulation values for $\mathrm{B}-$ may be underestimated because no equivalent correction value existed for that treatment with which to adjust for inoculum-introduced $\alpha$-glucan that was fermented. With $\mathrm{L}+$ values representing protozoal + bacterial glycogen, $\mathrm{B}-\mathrm{L}+$ and $\mathrm{B}+\mathrm{L}+$ accounted for 9.1 and $5.1 \%$ of added glucose, respectively, representing a $44 \%$ decrease in net glycogen accumulation with large IP removed.

Bacteria accumulated more glycogen in the absence of large IP. With net accumulated bacterial glycogen estimated as $\mathrm{L}+$ minus $\mathrm{L}-$, bacteria accounted for $49 \%$ $(3.13 \mathrm{mg})$ of the glycogen detected when large IP were present and the amount increased by $62 \%$ (to $5.07 \mathrm{mg}$ ) when large IP were absent. An apparent effect of large IP is to increase the total amount of glucose substrate

Table 1. Net microbial glycogen accumulation at $3 \mathrm{~h}$ of fermentation ${ }^{1}$

\begin{tabular}{|c|c|c|c|c|c|c|c|c|}
\hline \multirow[b]{2}{*}{ Item } & \multicolumn{2}{|c|}{ No blending } & \multicolumn{2}{|c|}{ Blended } & \multirow[b]{2}{*}{$\mathrm{SED}^{2}$} & \multicolumn{3}{|c|}{$P$-value } \\
\hline & - Lysis & + Lysis & - Lysis & + Lysis & & Blend & Lysis & $\begin{array}{l}\text { Blend } \\
\times \text { lysis }\end{array}$ \\
\hline
\end{tabular}


converted to glycogen and reduce the amount of glucose available to bacteria.

Factors that can affect glycogen accumulation by microbes can be manipulated through diet or experimental conditions. Increases in the concentration of sugars increased glycogen accumulation in isotrichids in vitro (Prins and Van Hoven, 1977), whereas increases in dietary protein concentration decreased the proportion of glycogen per unit of dry bacterial cells in vivo (McAllan and Smith, 1974). The measured range of glycogen (g/ $\mathrm{kg}$ of dry bacterial cells) in the in vivo study was 145 to $48 \mathrm{~g} / \mathrm{kg}$, respectively, on diets containing 16 to $46 \mathrm{~g}$ of $\mathrm{N} / \mathrm{kg}$ of diet DM. Even with an elevated ratio (1.2:1) of glucose to $\mathrm{CP}$ in the in the present study, the estimates of glycogen $(\mathrm{g} / \mathrm{kg}$ of dry microbial mass) were 135 and $246 \mathrm{~g} / \mathrm{kg}$ for $\mathrm{B}+\mathrm{L}+$ and $\mathrm{B}-\mathrm{L}+$, respectively. The $\mathrm{B}+\mathrm{L}+$ treatment, likely most comparable to the in vivo study values because it should have the greatest proportion of bacteria in the cell mass, falls very close to the $145 \mathrm{~g}$ of glycogen $/ \mathrm{kg}$ of dry bacterial cells reported for weaned calves on a lower protein diet (McAllan and Smith, 1974). In that study, starch from flaked maize was the supplemental NFC source and the diet had a ratio of starch to CP of approximately 3.7:1; the ratio of total fermentable carbohydrate to $\mathrm{CP}$ would be greater. The in vitro and in vivo glycogen accumulation results raise two questions: whether glucose or other soluble carbohydrates can lead to greater glycogen accumulation than noted for starch in vivo, and what effect altering the dietary concentrations of sugars or ratio of $\mathrm{N}$ :sugar substrate would have on glycogen accumulation with mixed ruminal microbes in vivo.

Unless glycogen passes from the rumen unfermented, glycogen storage should not change the final amount of $\mathrm{C}$ in fermentation products because it is eventually fermented. A possible benefit of passage of glycogen to the small intestine would be provision of another source of $\alpha$-glucan for direct digestion by the animal. Although it would reduce overall microbial product production, a reduction in carbohydrate fermentation could diminish production of gasses including methane. The potential also exists for glycogen digested in the small intestine to increase milk protein production as starch, which is also an $\alpha$-glucan, has been shown to do (Rius et al., 2010). Among the challenges to describing whole-animal effects of microbial glycogen storage will be estimating the proportion of dietary hexose that passes from the rumen unfermented.

Microbial $C$ and $N$. Despite differences in the amount of glycogen accumulated, no differences were found in the amount of $\mathrm{C}$ accumulated in the fermentation pellets of $\mathrm{B}-$ or $\mathrm{B}+$ treatments, reflecting differences in composition of the insoluble fermentation products (Table 2). Nitrogen accumulation increased by
$17.7 \%$ in $\mathrm{B}+$ relative to $\mathrm{B}-$. These results agree with decreases in microbial $\mathrm{N}$ synthesis from $\mathrm{OM}$ digested reported for faunated compared with unfaunated ruminants (Veira, 1986) that has been ascribed to protozoal predation. However, the substantial increase in microbial $\mathrm{N}$ noted in the present experiment is not likely due to decreased protozoal predation. Not all protozoa were destroyed in $\mathrm{B}+$, and, further, digestion and disappearance of mixed ruminal bacteria by protozoa is relatively slow, with first digestion products reported at $5 \mathrm{~h}$ after ingestion of bacteria (Coleman and Sandford, 1980). Bacteria produced during the in vitro fermentation and ingested by the protozoa would not have been digested within the 3 -h fermentation time used in the present experiment.

Several factors related to glycogen storage may have combined to alter microbial $\mathrm{N}$ accumulation. Conversion of hexose to glycogen reduces the availability of glucose for more immediate fermentation, growth and other purposes, and reduces availability of glucose substrate to microbial populations that have not sequestered it. Accumulation of glycogen also introduces an energy cost associated with storage. The incorporation of glucose into glycogen requires 1 ATP per glucose (Ball and Morell, 2003), which is 25 to $33 \%$ of the 3 to 4 ATP gained from direct fermentation of a hexose (Russell and Wallace, 1988). The ATP to synthesize glycogen from the 7.2 and $4.1 \mathrm{mg}$ of glucose accumulated in $\mathrm{B}-\mathrm{L}+$ and $\mathrm{B}+\mathrm{L}+$, respectively, can be provided by fermentation of 2.0 and $1.2 \mathrm{mg}$ of glucose, respectively, assuming a yield of 3.5 ATP per glucose. Because glucose is simultaneously added to and mobilized from the glycogen pool (Prins and Van Hoven, 1977), the energetic costs of glycogen synthesis are likely underestimated, because the point measurement of glycogen underestimates the amount of glucose that has passed through that pool. Summing the amount of glucose in glycogen and that required to support polymerization, a total of 9.2 and $5.3 \mathrm{mg}$ of glucose or 12.5 and $6.8 \%$ of substrate glucose were involved in glycogen synthesis in $\mathrm{B}-\mathrm{L}+$ and $\mathrm{B}+\mathrm{L}+$, respectively. The energy in the stored glycogen had not yet been used for microbial maintenance or growth, and the glucose used for synthesis was unavailable for other purposes. These results are neither positive nor negative, but are items to be considered when we estimate temporal production of microbial products and microbial ATP allocation.

Differences in the rates of fermentation of glucose and glycogen may also have played a part in generating the results apparently related to glycogen storage. Although glucose has been reported to disappear from the rumen at more than $400 \% \mathrm{~h}^{-1}$ (Weisbjerg et al., 1998), the actual rate of fermentation may be much slower. Rates of fermentation for sugars of 29 to $34 \% \mathrm{~h}^{-1}$ have 
Table 2. Fermentation products from glucose substrate at $3 \mathrm{~h}$ of fermentation

\begin{tabular}{|c|c|c|c|c|}
\hline Item & $\begin{array}{c}\text { No } \\
\text { blending }\end{array}$ & Blended & SED $^{1}$ & $P$-value \\
\hline \multicolumn{5}{|l|}{ Fermentation pellet } \\
\hline $\mathrm{N}, \mathrm{mg}$ & 2.20 & 2.60 & 0.10 & $<0.01$ \\
\hline $\mathrm{C}, \mathrm{mg}$ & 10.18 & 10.22 & 0.33 & 0.90 \\
\hline Total OA,$^{2} \mathrm{mmol}$ & 0.488 & 0.519 & 0.027 & 0.32 \\
\hline \multicolumn{5}{|l|}{ Molar percentages } \\
\hline Acetate & 38.9 & 34.5 & 1.14 & 0.02 \\
\hline Propionate & 47.0 & 49.4 & 1.68 & 0.23 \\
\hline Butyrate & 11.6 & 9.1 & 0.37 & $<0.01$ \\
\hline Valerate & 1.4 & 0.9 & 0.55 & 0.41 \\
\hline Lactate & 1.3 & 6.1 & 1.15 & 0.01 \\
\hline $\mathrm{BCVFA},{ }^{3} \mathrm{mmol}$ & 0.008 & 0.009 & 0.0008 & 0.25 \\
\hline $\mathrm{CO}_{2}, \mathrm{mmol}$ & 0.24 & 0.22 & 0.011 & 0.32 \\
\hline $\mathrm{CH}_{4}, \mathrm{mmol}$ & 0.065 & 0.049 & 0.005 & 0.03 \\
\hline
\end{tabular}

${ }^{1} \mathrm{SED}=$ standard error of the difference.

${ }^{2}$ Total OA (organic acids) = sum of acetate, propionate, butyrate, valerate, and lactate

${ }^{3} \mathrm{BCVFA}=$ branched-chain volatile fatty acids.

been reported (measured on the rapidly fermenting pool including sucrose, determined by gas production; Hall and Weimer, 2007). Intracellular polysaccharides such as glycogen are fermented somewhat more slowly in both ruminal bacteria $\left(23 \% \mathrm{~h}^{-1}\right.$; Van Kessel and Russell, 1997) and protozoa (15 to $17 \% \mathrm{~h}^{-1}$; calculated from data of Prins and Van Hoven, 1977). Rate of fermentation has been shown to influence the efficiency of microbial $\mathrm{N}$ production per unit of OM truly digested, with efficiency increasing (from 8.8 to $11.2 \mathrm{mg}$ of microbial N/g of OM truly digested) as rate of starch fermentation increased (from 0.04 to $0.20 \mathrm{~h}^{-1} ; P<0.001$ effect of treatment on efficiency; Sveinbjörnsson et al., 2006). Presuming that the rate of glucose fermentation is at least as great as that of sucrose, a one-third decrease in fermentation rate could potentially decrease the yield of microbial $\mathrm{N}$ from glycogen compared with glucose if the same amount of hexose is fermented.

Sequestration of glycogen by protozoa may also decrease microbial $\mathrm{N}$ production by diverting substrate from bacterial use. Protozoa are estimated to have a maintenance requirement $(8.5 \mathrm{mmol}$ of hexose $/ \mathrm{g}$ of protozoa per day or $0.064 \mathrm{~g}$ of hexose/g of protozoa per hour; Dijkstra, 1994) similar in magnitude to that of bacteria (0.022 to $0.187 \mathrm{~g}$ of carbohydrate/g of bacteria per hour; Russell et al., 1992). However, protozoa have a considerably longer doubling time (12.2 to $15.0 \mathrm{~h}$; Dehority, 2004) than do ruminal bacteria (62 to 130 min; Nagaraja and Taylor, 1987). The longer doubling time at similar maintenance requirements dictates that protozoa will be less efficient than bacteria in the production of cell mass per unit of carbohydrate fermented. So, although protozoa can help to maintain a more favorable ruminal environment by preventing ruminal $\mathrm{pH}$ depression from immediate fermentation of carbo- hydrates (Veira, 1986), their sequestration of carbohydrate substrate may play a significant role in reduction of microbial yield, exclusive of effects of protozoal predation. This hypothesis on the effect of carbohydrate sequestration by protozoa is supported by the research of Demeyer and Van Nevel (1979), who found that the specific rate of degradation of bacterial protein was not altered by defaunation, although the specific rates of total and net bacterial growth increased. This suggests an effect of protozoa other than predation, which could be the result of protozoa competing for substrate. Further, Wallace and McPherson, (1987) showed that the rate of bacterial protein breakdown tended to increase with numbers of small entodiniomorphid protozoa, but numbers of the larger entodiniomorphs and holotrichs (isotrichids) "had no obvious influence." If so, the elimination of the IP in the present experiment should have had a limited effect on the microbial turnover and protein breakdown associated with protozoal predation; their absence would not have been expected to increase microbial $\mathrm{N}$ accumulation if other protozoal numbers were maintained.

Organic Acids and Gases. Total organic acid production and the amount of $\mathrm{C}$ in organic acids did not differ between $\mathrm{B}+$ and $\mathrm{B}-$ (Table 2). Molar percentages of acetate and butyrate were greater for $\mathrm{B}-$ and that of lactate was greater for $\mathrm{B}+$. The butyrate results are consistent with reports that greater molar proportions of butyrate are found in faunated compared with defaunated sheep (Koenig et al., 2000). It has been shown that exogenous lactate is cleared more rapidly, and concentrations of lactate in the rumen are decreased in faunated compared with defaunated animals (Chamberlain et al., 1983). The greater lactate found in $\mathrm{B}+$ could also be a result of lessened glycogen storage 
in protozoa and availability of that glucose to lactateproducing bacteria. Although $\mathrm{CO}_{2}$ production did not differ by blending treatment, calculated $\mathrm{CH}_{4}$ production was greater with $\mathrm{B}-$, which agrees with reports of greater methane emissions for faunated sheep (Morgavi et al., 2008).

Soluble Carbohydrates in Fermentation Medium. Soluble carbohydrates detected in the fermentation medium may come from microbes or partially degraded plant materials. Free mannose was found only in 3-h fermentations to which glucose had been added (Table 3). Among the sugars released by hydrolysis, at $3 \mathrm{~h}$, rhamnose, mannose, glucose, and total released sugars were present in greater concentrations when glucose was a substrate than in fermentation blanks, and galactose tended to show the same response. Mannose was the only hydrolysis-released sugar to show an effect of blending treatment, with a tendency to show a greater increase with the addition of glucose in $\mathrm{B}+$ than in B- (Table 3). Xylose and arabinose showed no change in concentration with the addition of glucose or by blending treatment, suggesting that they are fragments of plant carbohydrates introduced with the inoculum. Compared with the sum of GC-measured sugars, values for the phenol-sulfuric acid assay showed the same pattern of response, but were approximately twice the amount. It is not known whether this indicates measurement of carbohydrate not detected with the GC method or is an artifact of using glucose as the standard for the phenol-sulfuric acid assay when many different monosaccharides were present. Phenolic compound-based colorimetric determinations of carbohydrate have been commonly used for analysis of fermentation media (Van Kessel and Russell, 1997).

Although the free and hydrolysis-released sugar values were small compared with the mass of glucose added, the apparent transformation of added glucose into other monosaccharides and incorporation of free glucose into a soluble polymer indicate that disappearance of free glucose does not assure that it has been fermented or permanently associated with microbial mass. These results suggest that microbes are converting glucose substrate to other hexoses and polymerized carbohydrate. Microbes have been shown to isomerize hexoses and produce exopolysaccharides (Laws et al., 2001). However, it is also possible that some portion of the soluble carbohydrates resulted from enhanced hydrolysis but not fermentation of feed substrates (Coen and Dehority, 1970) when glucose was supplemented.

The decrease in soluble carbohydrate over time in fermentation blanks is indicative of fermentation of those substrates (Table 4). Amounts of free glucose and rhamnose, mannose, glucose, and total sugars released by hydrolysis all declined with time. Free glucose decreased to a greater extent in $\mathrm{B}+$ than in $\mathrm{B}-$, and rhamnose tended to do the same. Released xylose, arabinose, and galactose showed no change in amount by treatment or fermentation hour, indicating that no net fermentation of these carbohydrates occurred. Values for total carbohydrate as measured with the phenol-sulfuric acid assay followed the same pattern as the total released sugars measured by GC, but the values were greater.

Table 3. Soluble carbohydrate in cell-free supernatant at $3 \mathrm{~h}$ of fermentation with or without glucose substrate $(0 \text { or } 78.75 \mathrm{mg} \text { of glucose })^{1}$

\begin{tabular}{|c|c|c|c|c|c|c|c|c|}
\hline Item & \multicolumn{2}{|c|}{ No blending } & \multicolumn{2}{|c|}{ Blended } & $\mathrm{SED}^{2}$ & \multicolumn{3}{|c|}{$P$-value ${ }^{3}$} \\
\hline Free mannose, mg & 0 & 0.045 & 0 & 0.043 & 0.002 & 0.48 & $<0.01$ & 0.48 \\
\hline \multicolumn{9}{|l|}{ Released by $\mathrm{TFA}^{4}$ hydrolysis, mg } \\
\hline Rhamnose & 0.118 & 0.177 & 0.110 & 0.168 & 0.008 & 0.16 & $<0.01$ & 0.88 \\
\hline Xylose & 0.005 & 0.007 & 0.005 & 0.007 & 0.006 & 0.92 & 0.64 & 0.92 \\
\hline Glucose & 0.488 & 1.903 & 0.392 & 1.688 & 0.317 & 0.50 & $<0.01$ & 0.79 \\
\hline Total released sugars, mg & 0.775 & 2.273 & 0.688 & 2.082 & 0.326 & 0.56 & $<0.01$ & 0.83 \\
\hline $\begin{array}{l}\text { Sum of sugars responding to glucose } \\
\text { corrected for } 0 \text {-h value, }{ }^{5} \mathrm{mg}\end{array}$ & -0.915 & 0.590 & -0.780 & 0.660 & 0.386 & 0.64 & $<0.01$ & 1.00 \\
\hline Total carbohydrate (phenol-sulfuric), mg & 2.91 & 6.14 & 2.62 & 5.37 & 0.532 & 0.19 & $<0.01$ & 0.53 \\
\hline
\end{tabular}

\footnotetext{
${ }^{1}$ Not corrected for 0 -h values except as noted.

${ }^{2} \mathrm{SED}=$ standard error of the difference.

${ }^{3} \mathrm{Glc}=$ glucose addition; $\mathrm{B} \times \mathrm{G}=$ interaction of blending treatment and glucose amount.

${ }^{4} \mathrm{TFA}=$ trifluoroacetic acid.

${ }^{5}$ Sum of sugars responding to glucose $=$ free mannose + released rhamnose, mannose, galactose, and glucose as measured by GC.
} 
Table 4. Carbohydrate in cell-free supernatant at 0 and $3 \mathrm{~h}$ of fermentation with no added glucose substrate

\begin{tabular}{|c|c|c|c|c|c|c|c|c|}
\hline Item & \multicolumn{2}{|c|}{ No blending } & \multicolumn{2}{|c|}{ Blended } & $\mathrm{SED}^{1}$ & \multicolumn{3}{|c|}{$P$-value ${ }^{2}$} \\
\hline Free glucose, mg & 0.182 & 0.155 & 0.338 & 0.082 & 0.044 & 0.21 & $<0.01$ & $<0.01$ \\
\hline \multicolumn{9}{|l|}{ Released by $\mathrm{TFA}^{3}$ hydrolysis, mg } \\
\hline Rhamnose & 0.122 & 0.118 & 0.135 & 0.110 & 0.007 & 0.60 & $<0.01$ & 0.06 \\
\hline Galactose & 0.102 & 0.105 & 0.118 & 0.115 & 0.011 & 0.15 & 1.00 & 0.76 \\
\hline Glucose & 1.322 & 0.488 & 1.085 & 0.392 & 0.223 & 0.31 & $<0.01$ & 0.66 \\
\hline Total sugars ${ }^{4}$ & 1.692 & 0.775 & 1.475 & 0.688 & 0.228 & 0.36 & $<0.01$ & 0.69 \\
\hline Total carbohydrate (phenol-sulfuric), mg & 4.33 & 2.91 & 4.28 & 2.62 & 0.359 & 0.52 & $<0.01$ & 0.66 \\
\hline
\end{tabular}

${ }^{1} \mathrm{SED}=$ standard error of the difference.

${ }^{2} \mathrm{~h}=$ hour of fermentation; $\mathrm{B} \times \mathrm{h}=$ interaction of blending treatment and hour of fermentation.

${ }^{3} \mathrm{TFA}=$ trifluoroacetic acid.

${ }^{4}$ Sum of free mannose + all released monosaccharides as measured by GC.

Temporal Pattern of Microbial ATP Requirements Related to Glucose Transport and Glycogen Synthesis. The uptake of nearly all glucose substrate by $3 \mathrm{~h}$ of fermentation agrees with the rapid glucose disappearance values reported in vivo by Weisbjerg et al. (1998), and describes a substrate that would be difficult to portray accurately in substrate-limited, steady-state systems. Unlike the situation with cell wall fiber, where microbes slowly obtain carbohydrate from the feed matrix and transport it into the cell over time, it appears that the energetic costs for glucose transport and glycogen synthesis of a free glucose substrate should be allocated only to the early hours of fermentation. These energy costs are not part of growth or maintenance per se. This temporal allocation could alter estimates of energy costs per unit of microbial cells produced, in part depending upon the time of cost determination relative to introduction of a substrate and subsequent fates of the microbes produced.

Quantitatively, the cost of transport and glycogen synthesis was approximately equivalent to $30 \%$ of the glucose substrate that disappeared in the present study. At a cost of 1 ATP per glucose for transport into the cell (Stouthamer, 1973), 434 (in B-) and 435 (in B+) $\mu \mathrm{mol}$ of ATP were expended for glucose transport within the first $3 \mathrm{~h}$ of fermentation. This is equivalent to ATP generated from $22.3(\mathrm{~B}-)$ and $22.4(\mathrm{~B}+) \mathrm{mg}$ of fermented glucose (assumed yield of $3.5 \mu \mathrm{mol}$ of ATP/ $\mu \mathrm{mol}$ of glucose fermented). Combined with the cost of glucose fermented to support glycogen synthesis of 2.0 $(\mathrm{B}-)$ and $1.2(\mathrm{~B}+) \mathrm{mg}$, the totals of glucose fermented to support the energetic costs of hexose transport and glycogen synthesis are $24.3(\mathrm{~B}-)$ and $23.6(\mathrm{~B}+) \mathrm{mg}$. With calculated estimates of nonpolysaccharide cell masses of $19.6(\mathrm{~B}-)$ and $23.2(\mathrm{~B}+) \mathrm{mg}($ as cell N/0.112; Pavlostathis et al., 1988) and a 3-h fermentation, the costs related to transport and glycogen synthesis were $0.41(\mathrm{~B}-)$ and $0.34(\mathrm{~B}+) \mathrm{g}$ of carbohydrate/g of microbial cells per hour. These values are approximately double the $0.15 \mathrm{~g}$ of carbohydrate/g of NFC bacteria per hour for maintenance requirements suggested by Russell et al. (1992) and do not include the true maintenance costs of the microbes. These values are likely underestimations of the energy costs because estimates for cell mass at the end of $3 \mathrm{~h}$ were applied to the entire fermentation time, and because, as described earlier, costs of glycogen synthesis are likely underestimated. Dividing the transport and synthesis costs by a greater microbial yield or by a longer period, either of which might result from a longer period of fermentation, will decrease the transport and glycogen synthesis costs per gram of microbial cells per hour by averaging them over larger denominators. However, if in vivo the microbes lyse or pass from the rumen without additional adjustments for time or cell growth, higher energetic costs will apply to the production of those cells. This suggests that calculations of energetic costs per gram of microbial cells per hour are very dependent on the time of determination relative to the time of introduction of a glucose substrate in systems that are not steady state. In a previous in vitro study, although sucrose and its monomer constituents essentially disappeared from the medium by $4 \mathrm{~h}$ of fermentation, maximum detected microbial accumulation of $\mathrm{N}$ occurred through $8 \mathrm{~h}$ in fermentations containing 4 and $6 \%$ sucrose (Hall and Weimer, 2007). In that study, fermentations with $2 \%$ sucrose showed maximum detected microbial $\mathrm{N}$ at 4 h. Those results would support the concept that sugar 
transport and glycogen synthesis costs are accrued early in the fermentation, although growth could continue after depletion of substrate in the fermentation medium. The time interval between substrate disappearance and maximum microbial growth could depend on substrate concentration, with greater substrate concentrations producing a longer interval, which may be related to the quantity of glycogen stored.

Implications for Carbon Accounting. A basic goal of fermentation studies in closed systems is to quantitatively account for the fate of the substrate. Meeting this goal depends on definitions of what we count as substrates, what we measure as products, and the accuracy of our methods, measurements, and calculations. With glucose as the sole substrate, almost $100 \%$ of the substrate carbon can be accounted for in cell pellet, organic acids, $\mathrm{CO}_{2}, \mathrm{CH}_{4}$, and soluble carbohydrate, with organic acids alone representing 52 to $55 \%$ of the total (Table 5). The yield of organic acids falls within a previously reported range (Hall and Weimer, 2007). However, glucose was not the only substrate $\mathrm{C}$ available to the microbes. Hristov et al. (2005) reported that $61.5 \%$ of the $\mathrm{N}$ incorporated into the mass of ruminal microbes supplied with glucose in vivo did not come from ammonia, but from AA and peptides, which are also sources of $\mathrm{C}$. Using this value to correct for the amount of microbial $\mathrm{C}$ that may come from AA and peptides rather than from glucose, the fate of approximately $15 \%$ of the glucose substrate C cannot be explained based on the products measured (cell pellet $\mathrm{C}$, organic acid $\mathrm{C}$ ) and calculated gas $\mathrm{C}$ (Table 5). If a lesser proportion of peptides and AA than found by Hristov et al. (2005) were incorporated by the microbes, the discrepancy in $\mathrm{C}$ recovery would be reduced (e.g., if AA + peptides $=33 \%$ of utilized $\mathrm{N}$, unaccounted substrate $\mathrm{C}$ is approximately 10\%). The gap in substrate $\mathrm{C}$ recovery is of concern because we do rely on measures of yields of fermentation products to predict ruminal conversion of dietary constituents into nutrients available to the animal.

Errors or artifacts within methods and failure to measure all microbial products could account for at least a portion of the discrepancy. Lysis of cells due to handling during the experiment would release cell contents into the fermentation medium where they would not be measured because they were no longer associated with intact cells. Correction of organic acid values using fermentation blanks requires that fermentation blanks be equivalent to fermentation vessels containing substrate. This means that fermentation of feed particles introduced with the inoculum and of amino $\mathrm{N}$ in the medium must be equivalent. The greater likelihood is that, without substrate, more AA and microbial mass would be subject to fermentation in the fermentation blank. In the present study, the amount of organic acid $\mathrm{C}$ produced in the fermentation blanks between 0 and $3 \mathrm{~h}$ was 4.8 and $5.2 \mathrm{mg}$ for $\mathrm{B}-$ and $\mathrm{B}+$, respectively. Although unlikely, if all of the organic acid $\mathrm{C}$ in the fermentation blanks came exclusively from fermentation of material not fermented in the treatments, it would account for 6 to $7 \%$ of substrate glucose.

Some fates of ruminally utilized substrate $\mathrm{C}$ that are not normally considered or measured could partially account for the missing substrate $\mathrm{C}$, but the production for most of them tends to be low or they are not likely to be produced under the conditions of the present experiment. Caproate, a $6-\mathrm{C}$ organic acid, is produced from fermentation of glucose, but the molar percentage is typically small (1.27 to 2.54 for caproate + valerate was found in lactating dairy cows infused ruminally with $2.5 \mathrm{~kg}$ of glucose per day; Boudon et al., 2007). Methyl-glyoxal at concentrations of 3 to $4 \mathrm{mM}$ has been produced by Prevotella ruminicola but under conditions of glucose excess (50 $\mathrm{m} M$ glucose) and a low concentration of $\mathrm{N}$ (3.6 mM ammonia) (Russell, 1993). No peaks were observed on the organic acid chromatograms for this study to suggest that organic acid alcohols were produced in the fermentations. Acetylated or formylated AA or peptides (Coleman, 1967) can be released by protozoa after digestion of predated bacteria; however, such digestion products are not released until some $5 \mathrm{~h}$ after ingestion of bacteria (Coleman and Sandford, 1980), and so should only affect the microbes brought in with the inoculum. Alternatively, microbial cell contents including proteins, nucleic acids, and so on could be released by naturally occurring cell lysis with or without predation; the released cell contents would not be counted within the cell pellet as part of the microbial mass. It has been reported that as much as $50 \%$ of microbial mass turns over in the rumen, and that bacterial autolysis may play an important part in this recycling (Wells and Russell, 1996). Substantial cell lysis and an inability to measure contents of lysed cells could contribute to the missing $15 \%$ of substrate C. Determination of the fate of the unaccounted substrate C would be useful for assessing the supply of nutrients generated from the original glucose substrate.

Quantitative determination of the effect of factors affecting conversion of dietary carbohydrate to glycogen and the digestive fates of glycogen could be useful in more accurately determining the forms and amounts of nutrients available to the animal. Such information would enable more accurate diet formulation to support production and enhanced feed efficiency, and allow determination of optima for different dietary carbohydrate concentrations under different dietary regimens. 
Table 5. Carbon in glucose substrate and fermentation products

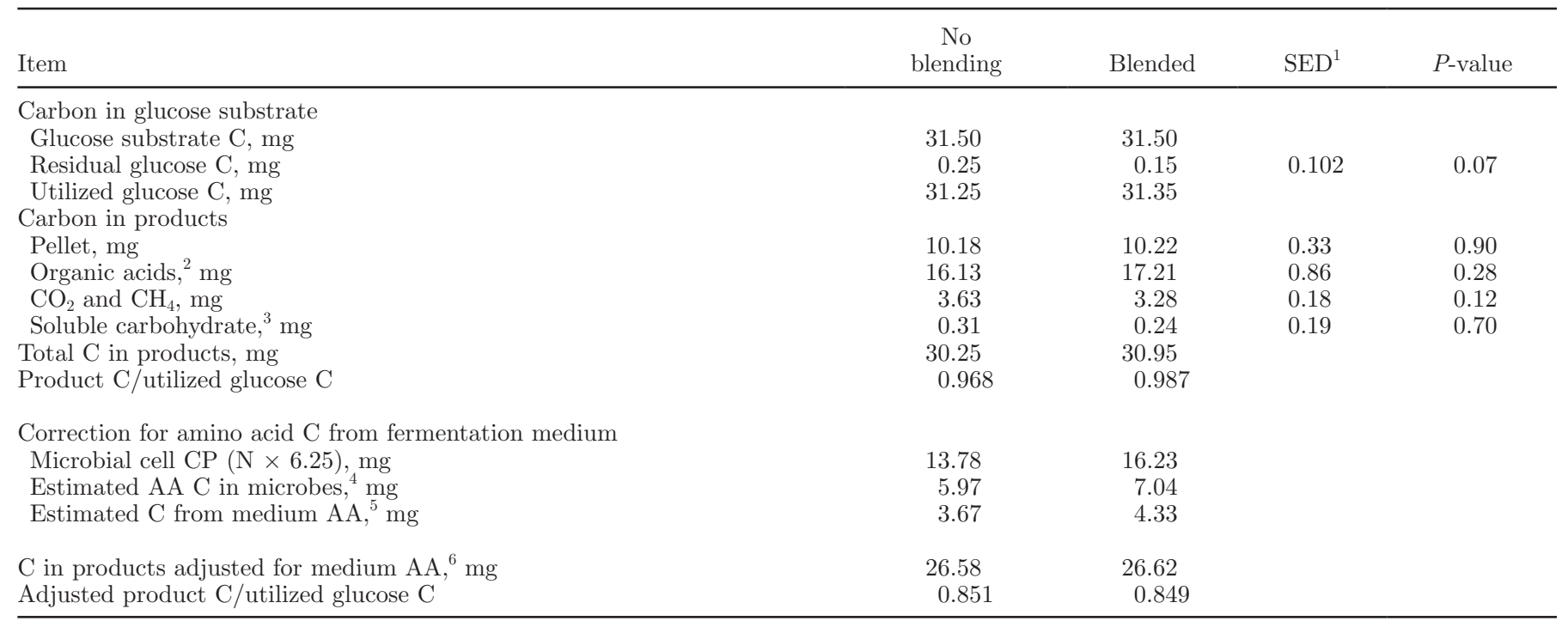

${ }^{1} \mathrm{SED}=$ standard error of the difference.

${ }^{2}$ Organic acids $=$ sum of acetate, propionate, butyrate, valerate, and lactate.

${ }^{3}$ Values for glucose substrate at $3 \mathrm{~h}$ of fermentation corrected for fermentation blank.

${ }^{4}$ Cell AA C estimated as $\mathrm{CP} \times 0.51 \mathrm{C}$ in $\mathrm{CP} \times 0.85$ of $\mathrm{N}$ as $\mathrm{AA}$ in microbial $\mathrm{CP}$.

${ }^{5}$ Cell AA $\mathrm{C} \times 0.615$, based on Hristov et al. (2005) that $61.5 \%$ of $\mathrm{N}$ in microbes supplied with glucose came from AA and peptides.

${ }^{6}$ Total $\mathrm{C}$ in products - estimated $\mathrm{C}$ from medium AA.

\section{CONCLUSIONS}

Glucose, and perhaps other water-soluble carbohydrates, may differ appreciably from our concepts of how rates of substrate disappearance, microbial energy demands, and microbial population profiles relate to production of microbial products. The relationships of large isotrichid protozoa with glycogen and microbial $\mathrm{N}$ accumulations, and the temporally skewed energetic demands created by glucose transport and glycogen synthesis in the early hours after introduction of a substrate fall outside the current frameworks used to describe rumen microbial function. The failure to account for possibly $15 \%$ of substrate $\mathrm{C}$ in the fermentations is problematic for accurately determining the types and amounts of nutrients potentially available to the animal from microbial action on glucose; it may be a problem with methodology, or microbes are producing materials that are not being measured. The results indicate the need to reevaluate our ability to account accurately for factors affecting conversion of sugars to nutrients usable by the cow if we are to better predict how to support desired animal performance with these dietary carbohydrates.

\section{ACKNOWLEDGMENTS}

The author thanks David Stevenson (USDA-ARS, Madison, WI) for ARISA analyses, and Paul J. Weimer
(USDA-ARS, Madison, WI) and the anonymous reviewers for their input.

\section{REFERENCES}

Ball, S. G., and M. K. Morell. 2003. From bacterial glycogen to starch: Understanding the biogenesis of the plant starch granule. Annu. Rev. Plant Biol. 54:207-233.

Boudon, A., P. Faverdin, R. Delagarde, P. Lamberton, and J. L. Peyraud. 2007. Effects of rumen or duodenal glucose infusions on intake in dairy cows fed fresh perennial ryegrass indoors. J. Dairy Sci. 90:4397-4410.

Broderick, G. A., N. D. Luchini, S. M. Reynal, G. A. Varga, and V. A. Ishler. 2008. Effect on production of replacing dietary starch with sucrose in lactating dairy cows. J. Dairy Sci. 91:4801-4810.

Broderick, G. A., and W. J. Radloff. 2004. Effect of molasses supplementation on the production of lactating dairy cows fed diets based on alfalfa and corn silage. J. Dairy Sci. 87:2997-3009.

Chamberlain, D. G., P. C. Thomas, and F. J. Anderson. 1983. Volatile fatty acid proportions and lactic acid metabolism in the rumen in sheep and cattle receiving silage diets. J. Agric. Sci. (Camb.) 101:47-58.

Clarke, K. R. 1993. Non-parametric multivariate analyses of changes in community structure. Aust. J. Ecol. 18:117-143.

Coen, J. A., and B. A. Dehority. 1970. Degradation and utilization of hemicellulose from intact forages by pure cultures of rumen bacteria. Appl. Microbiol. 20:362-368.

Coleman, G. S. 1967. The metabolism of the amino acids of Escherichia coli and other bacteria by the rumen ciliate Entodinium caudatum. J. Gen. Microbiol. 47:449-464.

Coleman, G. S., and D. C. Sandford. 1980. The uptake and metabolism of bacteria, amino acids, glucose and starch by the spined and spineless forms of the rumen ciliate Entodinium caudatum. J. Gen. Microbiol. 117:411-418.

Dehority, B. A. 2004. In vitro determination of generation times for Entodinium exiguum, Ophryoscolex purkynjei, and Eudiplodinium maggii. J. Eukaryot. Microbiol. 51:333-338. 
Demeyer, D. I., and C. J. Van Nevel. 1979. Effect of defaunation on the metabolism of rumen micro-organisms. Br. J. Nutr. 42:515-524.

Dijkstra, J. 1994. Simulation of the dynamics of protozoa in the rumen. Br. J. Nutr. 72:679-699.

El-Shazly, K. 1952. Degradation of proteins in the rumen of the sheep. 2. The action of rumen microorganisms on amino acids. Biochem. J. 51:647-653.

Goering, H. K., and P. J. Van Soest. 1970. Forage Fiber Analysis (Apparatus, Reagents, Procedures and Some Applications). Agriculture Handbook No. 379. Agricultural Research Service-USDA, Washington, DC.

Hall, M. B. 2009. Determination of starch, including maltooligosaccharides, in animal feeds: Comparison of methods and a method recommended for AOAC collaborative study. J. AOAC Int. 92:42-49.

Hall, M. B., and N. S. Keuler. 2009. Factors affecting accuracy and time requirements of a glucose oxidase-peroxidase assay for determination of glucose. J. AOAC Int. 92:50-60.

Hall, M. B., and P. J. Weimer. 2007. Sucrose concentration alters fermentation kinetics, products, and carbon fates during in vitro fermentation with mixed ruminal microbes. J. Anim. Sci. 85:1467-1478

Harris, P. J., A. B. Blakeney, R. J. Henry, and B. A. Stone. 1988. Gas chromatographic determination of the monosaccharide composition of plant cell wall preparations. J. AOAC 71:272-275.

Hristov, A. N., J. K. Ropp, K. L. Grandeen, S. Abedi, R. P. Etter, A. Melgar, and A. E. Foley. 2005. Effect of carbohydrate source on ammonia utilization in lactating dairy cows . J. Anim. Sci. 83:408-421.

Hungate, R. E. 1966. The Rumen and its Microbes. Academic Press, New York, NY.

Koenig, K. M., C. J. Newbold, F. M. McIntosh, and L. M. Rode. 2000 Effects of protozoa on bacterial nitrogen recycling in the rumen. J. Anim. Sci. 78:2431-2445.

Laws, A., Y. Gu, and V. Marshall. 2001. Biosynthesis, characterisation, and design of bacterial exopolysaccharides from lactic acid bacteria. Biotechnol. Adv. 19:597-625.

Marounek, M., K. Fliegrova, and S. Bartos. 1989. Metabolism and some characteristics of ruminal strains of Megasphaera elsdenii. Appl. Environ. Microbiol. 55:1570-1573.

Masson, F. M., and A. E. Oxford. 1951. The action of the ciliates of the sheep's rumen upon various water-soluble carbohydrates, including polysaccharides. J. Gen. Microbiol. 5:664-672.

McAllan, A. B., and R. H. Smith. 1974. Carbohydrate metabolism in the ruminant: Bacterial carbohydrates formed in the rumen and their contribution to digesta entering the duodenum. Br. J. Nutr. $31: 77-88$.

McCormick, M. E., D. D. Redfearn, J. D. Ward, and D. C. Blouin. 2001. Effect of protein source and soluble carbohydrate addition on rumen fermentation and lactation performance of Holstein cows. J. Dairy Sci. 84:1686-1697.

Morgavi, D. P., J.-P. Jouany, and C. Martin. 2008. Changes in methane emission and rumen fermentation parameters induced by refaunation in sheep. Aust. J. Exp. Agric. 48:69-72.

Murphy, M. R., P. E. Drone Jr., and S. T. Woodford. 1985. Factors stimulating migration of holotrich protozoa into the rumen. Appl. Environ. Microbiol. 49:1329-1331.

Nagaraja, T. G., and M. B. Taylor. 1987. Susceptibility and resistance of ruminal bacteria to antimicrobial feed additives. Appl. Environ. Microbiol. 53:1620-1625.
NRC. 2001. Nutrient Requirements of Dairy Cattle. 7th rev. ed. Natl. Acad. Press, Washington, DC.

Pavlostathis, S. G., T. L. Miller, and M. J. Wolin. 1988. Fermentation of insoluble cellulose by continuous cultures of Ruminococcus albus. Appl. Environ. Microbiol. 54:2655-2659.

Prins, R. A., and W. Van Hoven. 1977. Carbohydrate fermentation by the rumen ciliate Isotricha prostoma. Protistologica (Paris) $13: 549-556$

Rius, A. G., J. A. D. R. N. Appuhamy, J. Cyriac, D. Kirovski, O Becvar, J. Escobar, M. L. McGilliard, B. J. Bequette, R. M. Akers, and M. D. Hanigan. 2010. Regulation of protein synthesis in mammary glands of lactating dairy cows by starch and amino acids. J. Dairy Sci. 93:3114-3127.

Russell, J. B. 1993. Glucose toxicity in Prevotella ruminicola: Methylglyoxal accumulation and its effect on membrane physiology. Appl Environ. Microbiol. 59:2844-2850.

Russell, J. B., J. D. O'Connor, D. G. Fox, P. J. Van Soest, and C. J. Sniffen. 1992. A net carbohydrate and protein system for evaluating cattle diets: I. Ruminal fermentation. J. Anim. Sci. 70:35513561.

Russell, J. B., and R. J. Wallace. 1988. Energy yielding and consuming reactions. Pages 185-215 in The Rumen Microbial Ecosystem. P. N. Hobson, ed. Elsevier, Barking, UK.

Stouthamer, A. H. 1973. A theoretical study on the amount of ATP required for synthesis of microbial cell material. Antonie van Leeuwenhoek 39:545-565.

Sveinbjörnsson, J., M. Murphy, and P. Udén. 2006. Effect of the level of dry matter and protein and degradation rate of starch in vitro ruminal fermentation. Anim. Feed Sci. Technol. 130:191-203.

Thomas, G. J. 1960. Metabolism of the soluble carbohydrates of grasses in the rumen of the sheep. J. Agric. Sci. 54:360-372.

Van Kessel, J. S., and J. B. Russell. 1997. The endogenous polysaccharide utilization rate of mixed ruminal bacteria and the effect of energy starvation on ruminal fermentation rates. J. Dairy Sci. 80:2442-2448

Van Nevel, C. J., and D. I. Demeyer. 1979. Stoichiometry of carbohydrate fermentation and microbial growth efficiency in a continuous culture of mixed rumen bacteria. Eur. J. Appl. Microbiol Biotechnol. $7: 111-120$

Veira, D. M. 1986. The role of ciliate protozoa in nutrition of the ruminant. J. Anim. Sci. 63:1547-1560.

Wallace, R. J., and C. A. McPherson. 1987. Factors affecting the rate of breakdown of bacterial protein in rumen fluid. Br. J. Nutr. 58:313-323.

Weimer, P. J., Y. Shi, and C. L. Odt. 1991. A segmented gas/liquid delivery system for continuous culture of microorganisms on solid substrates, and its use for growth of Ruminococcus flavefaciens on cellulose. Appl. Microbiol. Biotechnol. 36:178-183.

Weimer, P. J., D. M. Stevenson, and D. R. Mertens. 2010. Shifts in bacterial community composition in the rumen of lactating dairy cows under milk fat-depressing conditions. J. Dairy Sci. 93:265278.

Weisbjerg, M. R., T. Hvelplund, and B. M. Bibby. 1998. Hydrolysis and fermentation rate of glucose, sucrose and lactose in the rumen. Acta Agric. Scand. A Anim. Sci. 48:12-18.

Wells, J. E., and J. B. Russell. 1996. The effect of growth and starvation on the lysis of the ruminal cellulolytic bacterium Fibrobacter succinogenes. Appl. Environ. Microbiol. 62:1342-1346.

Wolin, M. J. 1960. A theoretical rumen balance. J. Dairy Sci. $43: 1452-1459$ 